\title{
Kemampuan Siswa Memperoleh dan Memahami Konsep Hidrolisis Garam dalam Pembelajaran Menggunakan LKS Berbasis Belajar Penemuan pada Siswa Kelas XI SMAN 2 Palangka Raya Tahun Ajaran 2018/2019
}

The Student's Ability to Obtain and Understand The Concept of Salt Hydrolysis in Learning Using Learning Discovery-Based Worksheets in XI SMAN 2 Class Of Palangka Raya in The 2018/2019 Academic Year

\author{
Riska Meilani Simanjuntak ${ }^{1 *}$, Abudarin Abudarin ${ }^{2}$ \& \\ Karelius Karelius ${ }^{3}$ \\ 1,2 Jurusan Pendidikan MIPA/FKIP - Universitas Palangka Raya, \\ Palangka Raya - Indonesia 73111 \\ ${ }^{3}$ Program Studi Kimia FMIPA - Universitas Palangka Raya, Palangka \\ Raya - Indonesia 73111
}

*E-mail: meilaniriska99@gmail.com

\begin{abstract}
Abstrak
Materi larutan merupakan materi yang sulit bagi kebanyakan siswa, salah satunya materi hidrolisis garam. Penelitian ini bertujuan untuk mendeskripsikan kemampuan siswa memperoleh dan memahami konsep hidrolisis garam dari asam kuat dan basa lemah dalam pembelajaran menggunakan LKS berbasis belajar penemuan. Penelitian ini merupakan penelitian deskriptif. Subyek penelitian adalah siswa kelas XI MIPA SMA Negeri 2 Palangka Raya tahun ajaran 2018/2019 yang berjumlah 36 siswa. Instrumen yang digunakan berupa soal tes pemahaman konsep (pretes dan postes) dan LKS berbasis belajar penemuan. Data dikumpulkan melalui tiga tahap, yakni pretes, pelaksanaan pembelajaran, dan postes. Hasil penelitian menunjukkan bahwa kemampuan siswa dalam memperoleh konsep hidrolisis garam dari asam kuat dan basa lemah dalam pembelajaran menggunakan LKS berbasis belajar penemuan tercermin dari jumlah siswa yang memperoleh konsep, yaitu rata-rata sebesar $82,64 \%$. Pemahaman konsep siswa tentang hidrolisis garam dari asam kuat dan basa lemah dalam pembelajaran menggunakan LKS berbasis belajar penemuan rata-rata sebesar $89,81 \%$.
\end{abstract}

Kata kunci: hidrolisis garam, konsep, LKS, memahami, memperoleh

\begin{abstract}
Solution material is a difficult material for most students, one of which is salt hydrolysis. This study aims to describe the students' ability to obtain and understand the concept of salt hydrolysis from strong acids and weak bases in learning using discovery learning based worksheets. This research is a descriptive research. The research subjects were students of class XI MIPA at SMA Negeri 2 Palangka Raya in the 2018/2019 academic year, totaling 36 students. The instruments used were in the form of concept
\end{abstract}


comprehension test questions (pretest and posttest) and discovery learning-based worksheets. Data were collected through three stages, namely pretest, implementation of learning, and posttest. The results showed that the students' ability to obtain the concept of hydrolysis of salt from strong acids and weak bases in learning using discovery learning-based worksheets was reflected in the number of students who obtained the concept, namely an average of $82.64 \%$. Students' understanding of the concept of salt hydrolysis from strong acids and weak bases in learning using discovery-based worksheets an average of $89.81 \%$.

Keywords: salt hydrolysis, concepts, worksheets, understanding, obtaining 


\section{PENDAHULUAN}

Materi pelajaran kimia memerlukan kegiatan belajar yang tidak hanya sekadar mendengarkan ceramah atau membaca buku saja. Psikolog kognitif mengatakan bahwa kecil kemungkinan mendapatkan pengetahuan secara permanen jika siswa hanya belajar dengan mendengarkan ceramah atau membaca teks. Pengetahuan permanen dapat dibentuk melalui penerapan informasi baru dan menghubungkan informasi baru tersebut dengan informasi yang lainnya sehingga diperoleh suatu kesimpulan (Seçken \& Evrim, 2011). Pengetahuan bukanlah sesuatu yang diperoleh secara pasif melalui indera atau berbagai alat komunikasi yang ada di dunia luar (Açıkgöz, 2005 dalam Ulaş, dkk, 2012).

Pengetahuan dapat diperoleh dengan belajar. Belajar adalah suatu aktivitas atau proses untuk memperoleh pengetahuan, meningkatkan keterampilan, memperbaiki perilaku, sikap, dan memperkuat kepribadian (Suyono dan Hariyanto, 2012). Siswa yang telah belajar cara penulisan rumus senyawa kimia akan menuliskan rumus molekul air $\mathrm{H}_{2} \mathrm{O}$ bukan $\mathrm{H} 2 \mathrm{O}$. Hal ini menunjukkan bahwa makna yang diperoleh dari belajar adalah pemahaman terhadap suatu konsep.

Rosser (1984) dalam Dahar (2011) memaparkan bahwa konsep adalah suatu abstraksi yang mewakili satu kelas objek, kejadian, kegiatan, atau hubungan yang mempunyai atribut yang sama. KBBI V (2016) menjelaskan bahwa kata "paham" sebagai asal kata dari pemahaman dapat diartikan sebagai mengerti benar atau tahu benar atau sangat mengerti. Pemahaman merupakan proses, cara, perbuatan untuk memahamkan atau mengerti/mengetahui benar. Seorang individu dapat dikatakan paham mengenai sesuatu apabila individu tersebut sudah mengerti/mengetahui benar mengenai hal tersebut. Oleh karena itu, pemahaman konsep dapat diartikan yaitu memahami dan mengerti dengan benar suatu hubungan yang sederhana di antara fakta-fakta untuk menggambarkan secara abstrak suatu objek.

Pendidikan pada hakikatnya merupakan proses penemuan personal (personal discovery) oleh setiap individu siswa. Teori belajar penemuan dikemukakan oleh Jerome S. Bruner yang didasari oleh ungkapan Piaget bahwa siswa harus berperan secara aktif saat belajar di kelas. Siswa mengorganisasikan bahan pelajaran yang dipelajarinya untuk menemukan konsep yang sesuai dengan tingkat kemajuan berpikir siswa (Suyono dan Hariyanto, 2012).

Hidrolisis garam merupakan salah satu materi pelajaran kimia yang dipelajari di kelas XI semester genap. Latifah, Sugiharto, dan Nugroho (2014) menjelaskan bahwa materi hidrolisis garam merupakan salah satu materi pelajaran kimia yang di dalamnya terdapat konsep yang harus dipahami oleh siswa, antara lain konsep asam, basa, garam, reaksi penggaraman, $\mathrm{pH}$ larutan, dan konsep hidrolisis. Hidrolisis garam mengenalkan siswa tentang reaksi asam dengan basa yang membentuk garam beserta sifat-sifat dan identifikasinya (Utami, 2015).

Siswa kelas XI SMA dituntut agar mampu menguasai dan memahami berbagai jenis sifat suatu larutan apabila terjadi reaksi terhadap zat lain. Hal ini dapat dilakukan dengan mengamati peristiwa yang terjadi sehingga siswa mampu mengaplikasikannya dalam kehidupan sehari-hari. Materi larutan merupakan materi yang sulit bagi siswa pada umumnya, konsep pada materi ini harus dipahami siswa secara menyeluruh karena merupakan dasar mempelajari konsep kimia selanjutnya dalam kehidupan sehari-hari (Suyanti, 2010). 
Permasalahan tersebut dapat diatasi dengan cara menggunakan metode pembelajaran dan strategi pembelajaran yang dapat memudahkan pembelajaran hidrolisis garam dari asam kuat dan basa lemah. Konsep hidrolisis garam termasuk jenis pengetahuan yang diperoleh atau didasarkan dari fakta. Jumaini dalam Setianto (2017) mengungkapkan bahwa pembelajaran melalui praktikum juga dapat melatih keterampilan psikomotorik, kognitif, dan afektif.

LKS berbasis belajar penemuan merupakan LKS yang dirancang sedemikian rupa berdasarkan tahapan-tahapan belajar penemuan yang bertujuan melatih siswa memiliki alur berpikir dalam mempelajari suatu. Penggunaan LKS berbasis belajar penemuan, antara lain dapat meningkatkan keberhasilan belajar siswa, memantau kemajuan dan mendiagnosis kesulitan belajar siswa, dan mempermudah guru untuk menyampaikan materi (S. Masrura, 2017). Eksperimen dilakukan agar siswa dapat mengamati gejala-gejala yang terjadi, menganalisis serta menarik kesimpulan sehingga akan diperoleh konsep yang bukan sekadar bersifat hafalan.

Hasil penelitian Nurisalfah (2015) mengenai LKS menggunakan model discovery learning pada materi teori atom mekanika kuantum di SMA Negeri 1 Belitang diperoleh hasil belajar sebesar 91,67\%. Penelitian yang dilakukan oleh S. Masrura (2017) di MAS Oemar Diyan Aceh Besar tentang pembelajaran dengan menggunakan LKS berbasis discovery learning pada materi asam basa diperoleh pencapaian hasil belajar siswa yaitu $92,50 \%$.

Berdasarkan paparan di atas, perlu dikaji mengenai "kemampuan siswa memperoleh dan memahami konsep hidrolisis garam dalam pembelajaran menggunakan LKS berbasis belajar penemuan pada siswa kelas XI SMAN 2 Palangka Raya tahun ajaran 2018/2019”.

\section{BAHAN DAN METODE}

Penelitian ini merupakan jenis penelitian deskriptif. Subyek penelitian ini adalah siswa kelas XI MIPA SMAN 2 Palangka Raya tahun ajaran 2018/2019 sebanyak 36 orang siswa.

Teknik pengumpulan data dan instrumen yang digunakan disajikan pada Tabel 1.

Tabel 1. Teknik Pengumpulan Data dan Instrumen

\begin{tabular}{llc}
\hline \multicolumn{1}{c}{$\begin{array}{c}\text { Data yang } \\
\text { Diperoleh }\end{array}$} & \multicolumn{1}{c}{ Cara Mengumpulkan Data } & Instrumen \\
\hline $\begin{array}{l}\text { Pemahaman } \\
\text { konsep siswa }\end{array}$ & $\begin{array}{l}\text { Memberikan tes (pretes dan postes) } \\
\text { kepada siswa untuk dikerjakan secara } \\
\text { individu. }\end{array}$ & $\begin{array}{c}\text { Soal tes pemahaman } \\
\text { konsep (pretes dan } \\
\text { postes) }\end{array}$ \\
\hline $\begin{array}{l}\text { Kemampuan siswa } \\
\text { memperoleh }\end{array}$ & $\begin{array}{l}\text { Memberikan LKS berbasis belajar } \\
\text { penemuan kemudian memberikan skor }\end{array}$ & LKS berbasis belajar \\
konsep & $\begin{array}{l}\text { pada tahapan-tahapan belajar penemuan } \\
\text { yang dapat diselesaikan oleh siswa } \\
\text { sehingga siswa memperoleh konsep. }\end{array}$ & penemuan \\
\hline
\end{tabular}

Analisis data pemahaman konsep terdiri dari dua data, yaitu data pemahaman konsep sebelum pembelajaran (pretes) dan data pemahaman konsep setelah pembelajaran (postes). Data hasil pretes dan postes apabila sudah diperoleh, selanjutnya dilakukan analisis data dengan langkahlangkah sebagai berikut:

a. Memberikan skor hasil pretes dan postes siswa berdasarkan deksripsi pemahaman tiap indikator soal. Total skor yang diperoleh siswa dikonversikan dalam bentuk persentase pemahaman dengan cara sebagai berikut: 
Persentase pemahaman $=\frac{\text { Total skor siswa }}{\text { Total skor maksimum }} \times 100 \%$

b. Mentabulasi hasil pretes dan postes siswa yang sudah dalam bentuk persentase pemahaman dan memberikan kode pada setiap siswa.

c. Mengelompokkan skor hasil pretes dan postes siswa pada setiap butir soal kemudian menentukan kriteria tingkat pemahaman siswa berdasarkan pedoman yang digunakan.

d. Menganalisis peningkatan pemahaman konsep hidrolisis garam dari asam kuat dan basa lemah pada setiap indikator butir soal dari hasil pretes dan postes dengan cara sebagai berikut:

Pemahaman per indikator butir soal $=$

Total skor yang diperoleh untuk tiap butir soal

Total skor maksimum dari tiap butir soal $\mathrm{x}$ jumlah siswa $x 100 \%$

Peningkatan pemahaman siswa dihitung menggunakan N-gain, kemudian mentabulasikan dan mendeskripsikannya.

Pedoman yang digunakan untuk menyatakan tingkat pemahaman konsep siswa disajikan pada Tabel 2.

Tabel 2. Klasifikasi Tingkat Pemahaman

\begin{tabular}{ccc}
\hline Tingkat Pemahaman & Persentase Pemahaman (\%) & Kriteria \\
\hline I & $30-39$ & Kurang sekali \\
\hline II & $40-55$ & Kurang \\
\hline III & $56-65$ & Cukup \\
\hline IV & $66-79$ & Baik \\
\hline V & $80-100$ & Baik sekali \\
\hline
\end{tabular}

(Arikunto, 2013)

Data kemampuan siswa memperoleh konsep dianalisis melalui penilaian LKS berbasis belajar penemuan. Total skor maksimum LKS berbasis belajar penemuan adalah 115. Aspek yang dinilai pada LKS berbasis belajar penemuan terdiri dari delapan tahap, yaitu: (a) prasyarat pengetahuan skor maksimum 34; (b) stimulasi memiliki skor maksimum 5; (c) identifikasi masalah skor maksimum 8; (d) pengumpulan data skor maksimum 10; (e) pengolahan data skor maksimum 31; (f) pembuktian data skor maksimum 3; (g) penarikan kesimpulan skor maksimum 6; dan (h) latihan soal skor maksimum 18.Penentuan skor maksimum didasarkan oleh jumlah jawaban yang harus siswa isi/lengkapi pada setiap tahapan belajar penemuan yang ada dalam LKS berbasis belajar penemuan.

\section{HASIL}

Data nilai pretes dan postes siswa disajikan pada Tabel 3. Skor maksimal dari empat butir soal adalah 12 yang kemudian dikonversikan menjadi nilai dengan rentang 0 sampai 100 .

Data pada Tabel 3 menunjukkan nilai tertinggi yang diperoleh siswa saat pretes adalah 58,33 dan nilai terendah adalah 0,00 sedangkan nilai tertinggi yang diperoleh siswa saat postes adalah 100,00 dan nilai terendah adalah 50,00. Data pretes dan postes diperoleh dari tes pemahaman konsep yang terdiri dari empat butir soal essay. 
Tabel 3. Data Nilai Pretes dan Postes Siswa

\begin{tabular}{|c|c|c|c|}
\hline Kelompok & Kode Sisma & Nilai Pretes & Nilai Postes \\
\hline \multirow{5}{*}{ I } & I-l & 25,00 & 83,33 \\
\hline & I-2 & 16,67 & 83,33 \\
\hline & I-3 & 16,67 & 100,00 \\
\hline & I-4 & 8,33 & 100,00 \\
\hline & I-5 & 25,00 & 91,67 \\
\hline \multirow{5}{*}{ II } & II-1 & 41,67 & 100,00 \\
\hline & II-2 & 0,00 & 50,00 \\
\hline & II-3 & 0,00 & 100,00 \\
\hline & II-4 & 41,67 & 100,00 \\
\hline & II-5 & 16,67 & 83,33 \\
\hline \multirow{4}{*}{ III } & III-1 & 8,33 & 100,00 \\
\hline & III-2 & 0,00 & 100,00 \\
\hline & III-3 & 8,33 & 66,67 \\
\hline & III-4 & 8,33 & 58,33 \\
\hline \multirow{5}{*}{ IV } & IV-1 & 41,67 & 91,67 \\
\hline & IV-2 & 0,00 & 100,00 \\
\hline & IV-3 & 8,33 & 100,00 \\
\hline & IV-4 & 8,33 & 50,00 \\
\hline & IV-5 & 8,33 & 91,67 \\
\hline \multirow{4}{*}{$\mathrm{v}$} & V-1 & 8,33 & 66,67 \\
\hline & V-2 & 0,00 & 83,33 \\
\hline & V-3 & 16,67 & 75,00 \\
\hline & V-4 & 16,67 & 100,00 \\
\hline \multirow{4}{*}{ VI } & VI-1 & 16,67 & 58,33 \\
\hline & VI-2 & 0,00 & 75,00 \\
\hline & VI-3 & 8,33 & 50,00 \\
\hline & VI-4 & 16,67 & 66,67 \\
\hline \multirow{4}{*}{ VII } & VII-1 & 16,67 & 100.00 \\
\hline & VII-2 & 8,33 & 66,67 \\
\hline & VII-3 & 8,33 & 50,00 \\
\hline & VII-4 & 0,00 & 100,00 \\
\hline \multirow{5}{*}{ VIII } & VIII-1 & 0,00 & 100,00 \\
\hline & VIII-2 & 8,33 & 58,33 \\
\hline & VIII-3 & 58,33 & 91,67 \\
\hline & VIII-4 & 8,33 & 100,00 \\
\hline & VIII-5 & 41,67 & 75,00 \\
\hline
\end{tabular}

Tabel 4. Data Nilai LKS Siswa

\begin{tabular}{|c|c|c|c|c|c|c|c|c|c|c|}
\hline \multirow[b]{2}{*}{ Kade Sañ } & \multicolumn{8}{|c|}{ Skar Sefap Trapan } & \multirow[b]{2}{*}{$\begin{array}{l}\text { Shas } x \\
\text { Shim }\end{array}$} & \multirow[b]{2}{*}{ 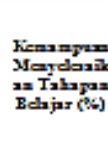 } \\
\hline & 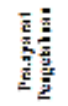 & 蒿 & $\frac{\sqrt[n]{\frac{\pi}{3}}}{\frac{\pi}{3}}$ & 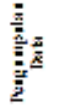 & 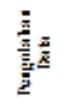 & $\frac{2}{3}$ & है & 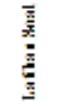 & & \\
\hline $\mathrm{I}-1$ & 34 & 3 & 0 & 9 & 30 & 3 & 6 & 11 & 95 & 33,48 \\
\hline $\mathrm{I}-2$ & 34 & 3 & 0 & 9 & 31 & 3 & 6 & 10 & 95 & $\$ 3,48$ \\
\hline $\mathrm{I}-3$ & 34 & 2 & 0 & 9 & 31 & 3 & 6 & 10 & 95 & $\$ 2,61$ \\
\hline $\mathrm{I}-4$ & 34 & 2 & 0 & 9 & 31 & 0 & 6 & 10 & 92 & $S O, D O$ \\
\hline I-5 & 32 & 3 & 0 & 9 & 30 & 3 & 6 & 11 & 94 & $\$ 1,74$ \\
\hline II-1 & 34 & 3 & 0 & 10 & 28 & 3 & 6 & 9 & 93 & 50,57 \\
\hline III-2 & 34 & 3 & 0 & 10 & 31 & 3 & 6 & 9 & 95 & $\$ 33,48$ \\
\hline II-3 & 34 & 3 & 0 & 10 & 28 & 3 & 6 & 10 & 94 & $\$ 1,74$ \\
\hline II-4 & 34 & 3 & 0 & 10 & 26 & 3 & 6 & 12 & 94 & $\$ 1,74$ \\
\hline III-5 & 34 & 3 & 0 & 10 & 31 & 3 & 6 & 11 & 98 & 35,22 \\
\hline III-1 & 34 & 3 & 1 & 9 & 31 & 3 & 6 & 18 & 105 & 91,30 \\
\hline III-2 & 34 & 3 & 1 & 3 & 31 & 3 & 6 & 3 & 94 & $\$ 1,74$ \\
\hline III-3 & 34 & 3 & 1 & 10 & 31 & 3 & 6 & 12 & 100 & $\$ 5,95$ \\
\hline III-4 & 32 & 3 & 1 & 9 & 30 & 3 & 6 & 3 & 92 & $S O, D O$ \\
\hline$\Gamma \mathrm{V}-1$ & 34 & 4 & 2 & 10 & 29 & 3 & 6 & 10 & 98 & 35,22 \\
\hline TV-2 & 34 & 4 & 1 & 10 & 30 & 3 & 4 & 3 & 94 & $\$ 1,74$ \\
\hline IV-3 & 34 & 4 & 2 & 10 & 28 & 3 & 6 & 18 & 105 & 91,30 \\
\hline $\mathrm{F}-4$ & 34 & 4 & 2 & 10 & 31 & 3 & 6 & 14 & 104 & 90,43 \\
\hline TV-5 & 34 & 4 & 2 & 10 & 31 & 3 & 6 & 16 & 106 & 92,17 \\
\hline $\mathrm{v}-1$ & 34 & 2 & 0 & 9 & 30 & 3 & 6 & 17 & 101 & $\$ 7,83$ \\
\hline $\mathrm{v}-2$ & 34 & 2 & 0 & 9 & 29 & 3 & 6 & 15 & 98 & 35,22 \\
\hline $\mathrm{v}-3$ & 34 & 2 & 0 & 10 & 30 & 3 & 6 & 15 & 100 & $\$ 5,95$ \\
\hline $\mathrm{v}-4$ & 34 & 2 & 0 & 9 & 31 & 3 & 6 & 17 & 102 & $\$ 8,70$ \\
\hline VI-1 & 34 & 2 & 0 & 9 & 31 & 3 & 6 & 11 & 95 & $\$ 33,48$ \\
\hline VI-2 & 33 & 2 & 0 & 9 & 29 & 3 & 6 & 16 & 98 & 35,22 \\
\hline VI-3 & 32 & 2 & 0 & 9 & 31 & 3 & 6 & 14 & 97 & 34,35 \\
\hline VI-4 & 33 & 2 & 0 & 6 & 31 & 3 & 6 & 12 & 93 & 50,57 \\
\hline VII-1 & 34 & 4 & 0 & 10 & 31 & 3 & 6 & 18 & 106 & 92,17 \\
\hline VII-2 & 32 & 4 & 0 & 10 & 27 & 3 & 6 & 15 & 97 & 34,35 \\
\hline VII-3 & 34 & 4 & 0 & 10 & 31 & 3 & 6 & 18 & 106 & 92,17 \\
\hline VII-4 & 34 & 4 & 0 & 10 & 31 & 3 & 6 & 18 & 106 & 92,37 \\
\hline VIII-1 & 34 & 4 & 1 & 6 & 29 & 3 & 6 & 14 & 97 & 34,35 \\
\hline VIII-2 & 34 & 4 & 1 & 9 & 28 & 3 & 6 & 10 & 95 & $\$ 2,61$ \\
\hline VIII-3 & 34 & 4 & 1 & 9 & 30 & 3 & 6 & 18 & 105 & 91,30 \\
\hline VIII-4 & 34 & 4 & 1 & 6 & 30 & 3 & 6 & 14 & 98 & 35,22 \\
\hline VIII-5 & 34 & 4 & 1 & 9 & 30 & 3 & 6 & 14 & 101 & 37,83 \\
\hline Jamhk & 1214 & 112 & 13 & 330 & 1073 & 105 & 214 & 471 & 3542 & $85,36 \%$ \\
\hline$*$ & 31,27 & 3,16 & 0,51 & 9,32 & 30,13 & 2,26 & 6,04 & 13,30 & & \\
\hline
\end{tabular}


Konsep tentang hidrolisis garam diperoleh melalui aktivitas belajar yang meliputi: (1) pengenalan garam-garam yang tersusun dari asam kuat dan basa lemah berdasarkan contoh beberapa jenis garam; (2) sifat larutan garam yang terbentuk dari asam kuat dan basa lemah berdasarkan percobaan menggunakan indikator kertas lakmus; (3) reaksi hidrolisis garam; dan (4) sifat larutan garam yang terbentuk dari asam kuat dan basa lemah berdasarkan reaksi hidrolisis (konsep teoritis). Data nilai LKS siswa disajikan pada Tabel 4.

Data siswa yang memperoleh konsep hidrolisis garam yang tersusun dari asam kuat dan basa lemah ditunjukkan pada Tabel 5.

Tabel 5. Data Kemampuan Siswa dalamMemperoleh Konsep Hidrolisis GaramyangTersusun dari Asam Kuat dan Basa Lemah

\begin{tabular}{|c|c|c|c|c|c|c|c|c|c|}
\hline \multirow{3}{*}{ Kel. } & \multirow{3}{*}{$\begin{array}{l}\text { Jumlah } \\
\text { Anggota }\end{array}$} & \multicolumn{8}{|c|}{ Jumlah Sisra yang Dapat Memperoleh Konsep } \\
\hline & & \multicolumn{2}{|c|}{ Konsep 1} & \multicolumn{2}{|c|}{ Konsep 2} & \multicolumn{2}{|c|}{ Konsep 3} & \multicolumn{2}{|c|}{ Konsep 4} \\
\hline & & Orang & $\%$ & Orang & $\%$ & Orang & $\%$ & Orang & $\%$ \\
\hline I & 5 & 4 & 80,00 & 5 & 100 & 3 & 60 & 5 & 100 \\
\hline II & 5 & 5 & 100,00 & 5 & 100 & 2 & 40 & 5 & 100 \\
\hline III & 4 & 3 & 75,00 & 3 & 75 & 4 & 100 & 4 & 100 \\
\hline IV & 5 & 5 & 100,00 & 5 & 100 & 4 & 80 & 4 & 80 \\
\hline $\mathrm{V}$ & 4 & 4 & 100,00 & 4 & 100 & 3 & 75 & 3 & 75 \\
\hline VI & 4 & 1 & 25,00 & 3 & 75 & 3 & 75 & 4 & 100 \\
\hline VII & 4 & 3 & 75,00 & 4 & 100 & 3 & 75 & 4 & 100 \\
\hline VIII & 5 & 5 & 100,00 & 3 & 60 & 1 & 20 & 5 & 100 \\
\hline Total & 36 & 30 & 83,33 & 32 & 88,89 & 23 & 63,89 & 34 & 94,44 \\
\hline \multicolumn{2}{|c|}{ Rata-rata } & \multicolumn{8}{|c|}{82,64} \\
\hline \multicolumn{2}{|c|}{$\begin{array}{c}\text { Tidak memperoleh } \\
\text { konsep } \\
\end{array}$} & 6 & 16,67 & 4 & 11,11 & 13 & 13,11 & 2 & 5,56 \\
\hline \multicolumn{2}{|c|}{ Rata-rata } & \multicolumn{8}{|c|}{17,36} \\
\hline
\end{tabular}

Rata-rata siswa yang dapat memperoleh konsep sebagaimana ditunjukkan pada Tabel 5 sebesar 82,64\% sedangkan siswa yang belum dapat memperoleh konsep dengan baik rata-rata sebesar $17,36 \%$. Hal ini berarti sebagian besar siswa sudah dapat memperoleh konsep dengan baik dalam pembelajaran menggunakan LKS berbasis belajar penemuan.

\section{PEMBAHASAN}

Peningkatan pemahaman konsep siswa didasarkan pada data hasil penilaian lembar jawaban pretes dan postes siswa dan dihitung menggunakan N-gain seperti yang ditunjukkan pada Tabel 6. Peningkatan pemahaman secara keseluruhan dianalisis lebih lanjut pada setiap indikator pembelajaran. Hasil peningkatan pemahaman siswa disajikan pada Tabel 7.

Data pada Tabel 7 menunjukkan bahwa pemahaman konsep siswa pada setiap indikator umumnya mengalami peningkatan meskipun besar peningkatannya masih kurang signifikan. Peningkatan pemahaman tertinggi terjadi pada konsep penentuan sifat larutan garam berdasarkan asam basa pembentuknya. Peningkatan pemahaman terendah terjadi pada konsep menuliskan reaksi hidrolisis garam yang tersusun dari asam kuat dan basa lemah. 
Tabel 6. Peningkatan Pemahaman Konsep Siswa pada Pretes dan

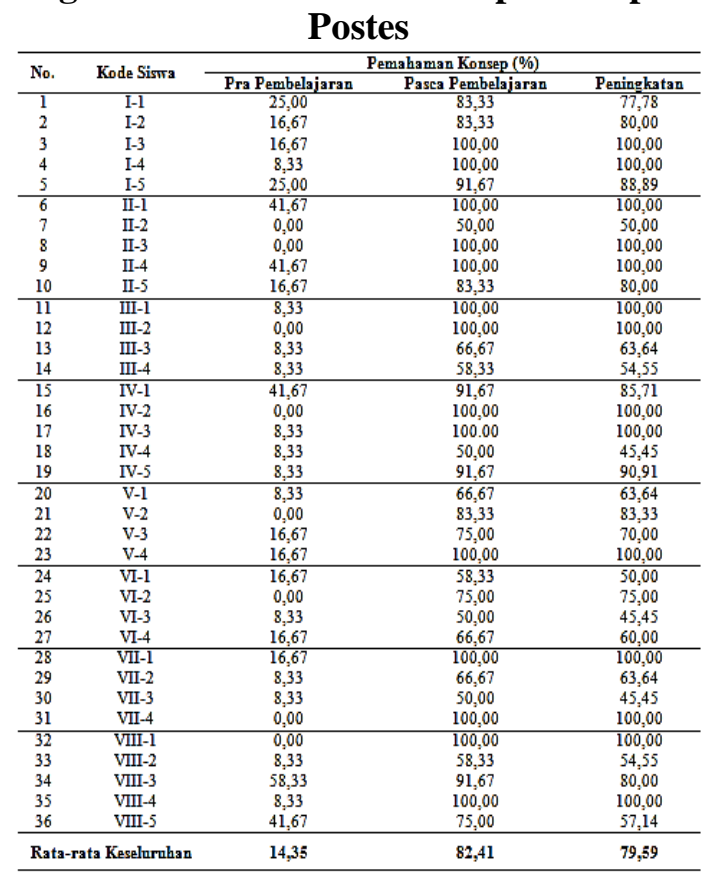

Tabel 7. Peningkatan Pemahaman Konsep Siswa pada Setiap

\begin{tabular}{|c|c|c|c|c|}
\hline \multirow[t]{2}{*}{ Indikstor } & \multirow[t]{2}{*}{ Tujuan Pembelajaran } & \multicolumn{2}{|c|}{$\begin{array}{l}\text { Pemahaman Konsep } \\
(\%)\end{array}$} & \multirow{2}{*}{$\begin{array}{l}\text { Peningkatan } \\
\text { Pemahamanan } \\
\text { Konsep (\%) }\end{array}$} \\
\hline & & Pretes & Postes & \\
\hline \multirow{2}{*}{$\begin{array}{l}\text { Menentukan sifat } \\
\text { larutan garam yang } \\
\text { terbentuk dari asam } \\
\text { kuat dan basa } \\
\text { lemah. }\end{array}$} & $\begin{array}{l}\text { Siswa dapat mengenali garam- } \\
\text { garam yang tersusum dari asam } \\
\text { kuat dan basa lemah. }\end{array}$ & 45,83 & 98,61 & 97,43 \\
\hline & $\begin{array}{l}\text { Siswa depat menentukan sifat } \\
\text { lanutan garam berdasarkan } \\
\text { asam basa pembentuknya. }\end{array}$ & 12,50 & 98,61 & 98,41 \\
\hline $\begin{array}{l}\text { Menuliskan reaksi } \\
\text { hidrolisis gearm } \\
\text { yang tersusum dari } \\
\text { asam kuat dan basa } \\
\text { lemah. }\end{array}$ & $\begin{array}{l}\text { Siswa dapat menuliskan reaksi } \\
\text { hidrolisis garam yang tersusum } \\
\text { dari asam kuat dan basa } \\
\text { lemah. }\end{array}$ & 6,94 & 67,59 & 65,17 \\
\hline \multirow[t]{2}{*}{$\begin{array}{l}\text { Menentukan sifat } \\
\text { larutan garam yang } \\
\text { tersusum dari asam } \\
\text { kuat dan basa lemah } \\
\text { berdasarkan reaksi } \\
\text { hidrolisis. }\end{array}$} & $\begin{array}{l}\text { Siswa dapat menentukkan sifat } \\
\text { lanutan garam yang tersusun } \\
\text { dari asam kuat dan basa lemah } \\
\text { berdasarkan reaksi hidrolisis. }\end{array}$ & 6,94 & 94,44 & 94,03 \\
\hline & Rata-rata & 18,06 & 89,81 & 88,76 \\
\hline
\end{tabular}

1. Konsep Pengenalan Garam-garam yang Tersusun dari Asam Kuat dan Basa Lemah Berdasarkan Contoh Beberapa Jenis Garam

Siswa yang mampu memperoleh konsep ini dilihat dari hasil kerja siswa pada LKS ada sebanyak $30(83,33 \%)$ siswa. Hal ini menunjukkan bahwa hampir seluruh siswa sudah dapat mengenali garam-garam yang berasal dari asam kuat dan basa lemah dari beberapa contoh jenis garam.Sebanyak $6(16,67 \%)$ siswa tidak berhasil memperoleh konsep ini dengan baik.

Pergeseran pemahaman siswa tentang konsep pengenalan garamgaram yang tersusun dari asam kuat dan basa lemah ditelusuri menggunakan butir soal 1a. Skor yang diberikan pada butir soal 1a berada pada rentang 0-2. Deskripsi pemahaman siswa dan skor disajikan pada Tabel 8. 
Tabel 8. Deskripsi Pemahaman dan Skor pada Butir Soal 1a

\begin{tabular}{|c|c|}
\hline Deskripsi Pemahaman & Skor \\
\hline Siswa tidak memahami (jawraban siswa tiddak relervan/salah). & 0 \\
\hline $\begin{array}{l}\text { Siswa dapat mengenali contoh lantan garam dari asam huat dan basa lemah yang } \\
\text { sefing dijadikan contoh dalam pembelajaran. }\end{array}$ & 1 \\
\hline $\begin{array}{l}\text { Siswa dapat mengenali contoh lanutan garam dari asam kuat dan basa lemah yang } \\
\text { jarang dijadikan coutoh dalam pembelajaran. }\end{array}$ & 2 \\
\hline
\end{tabular}

Data jumlah siswa pada tiap skor yang diperoleh saat pretes dan postes disajikan pada Tabel 9.

Tabel 9. Jumlah Siswa pada Tiap Skor saat Pretes dan Postes pada Butir Soal 1a

\begin{tabular}{ccccc}
\hline \multirow{2}{*}{ Skor } & \multicolumn{5}{c}{ Junlah Sista } \\
\cline { 2 - 5 } & \multicolumn{2}{c}{ Pretes } & \multicolumn{3}{c}{ Postes } \\
\cline { 2 - 5 } & Sisma & 96 & Sism & 96 \\
\hline 0 & 11 & 30,56 & - & - \\
\hline 1 & 17 & 47,22 & 1 & 2,78 \\
\hline 2 & 8 & 22,22 & 35 & 97,22 \\
\hline
\end{tabular}

Tabel 9 menunjukkan bahwa pada saat pretes dominan siswa hanya mampu mengenali larutan garam yang sering dijadikan contoh dalam pembelajaran yaitu sebanyak $17(47,22 \%)$ siswa. Pada akhir pembelajaran (postes) hanya $1(97,22 \%)$ siswa yang belum mampu mengenali larutan garam yang tersusun dari asam kuat dan basa lemah.

2. Konsep Sifat Larutan Garam yang Terbentuk dari Asam Kuat dan Basa Lemah Berdasarkan Percobaan Menggunakan Indikator Kertas Lakmus

Hasil kerja siswa pada LKS ada $32(88,89 \%)$ siswa yang mampu memperoleh konsep larutan garam yang tersusun dari asam kuat dan basa lemah bersifat asam. Hal ini menunjukkan bahwa hampir seluruh siswa berhasil menemukan konsep sifat (asam/basa) larutan garam yang tersusun dari asam kuat dan basa lemah.Siswa sebanyak $4(11,11 \%)$ orang tidak berhasil memperoleh konsep larutan garam yang tersusun dari asam kuat dan basa lemah bersifat asam.

Pergeseran pemahaman siswa tentang konsep sifat (asam/basa) larutan garam yang tersusun dari asam kuat dan basa lemah dapat dilihat dari butir soal $1 \mathrm{~b}$. Skor yang diberikan pada butir soal $1 \mathrm{~b}$ berada pada rentang 0-2. Deskripsi pemahaman siswa dan skor disajikan pada Tabel 10.

Tabel 10. Deskripsi Pemahaman dan Skor pada Butir Soal 1b

\begin{tabular}{|c|c|}
\hline Deskripsi Pemahaman & Skor \\
\hline 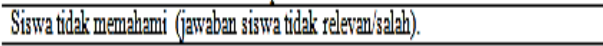 & 0 \\
\hline $\begin{array}{l}\text { Siswa dapat menentukan sifat asam atau basa dari lantan gatam yang seing } \\
\text { dijadikan contoh dalam pembolajaran. }\end{array}$ & 1 \\
\hline $\begin{array}{l}\text { Siswa dapat menentukan sifat asam atau basa dari lantan gram yang jarang } \\
\text { dijadikan contoh dalam pembelaiaran. }\end{array}$ & 2 \\
\hline
\end{tabular}

Data jumlah siswa pada tiap skor yang diperoleh saat pretes dan postes disajikan pada Tabel 11.

Tabel 11. Jumlah Siswa pada Tiap Skor saat Pretes dan Postes pada Butir Soal 1b

\begin{tabular}{ccccc}
\hline \multirow{3}{*}{ Skor } & \multicolumn{4}{c}{ Jumlah Sisma } \\
\cline { 2 - 5 } & \multicolumn{3}{c}{ Pretes } & \multicolumn{2}{c}{ Postes } \\
\cline { 2 - 5 } & Sisma & $\%$ & Sisma & $\%$ \\
\hline 0 & 28 & 77,78 & - & - \\
\hline 1 & 7 & 19,44 & 1 & 2,78 \\
\hline 2 & 1 & 2,78 & 35 & 97,22 \\
\hline
\end{tabular}

Tabel 11 menunjukkan bahwa sebagian besar siswa tidak mampu menentukan sifat larutan garam yang tersusun dari asam kuat dan basa 
lemah. Hal ini ditandai dengan peroleh skor 0 sebanyak 28 (77,78\%) siswa. Siswa pada saat postes hanya ada $1(2,78 \%)$ yang belum mampu mendapatkan skor 2. Hal ini berarti siswa tersebut hanya mampu menentukan sifat (asam/basa) larutan garam yang sering dijadikan contoh dalam pembelajaran saja.

\section{Konsep Reaksi Hidrolisis Garam}

Data pada Tabel 5 menunjukkan ada sebanyak $23(63,89 \%)$ siswa yang berhasil memperoleh konsep reaksi hidrolisis garam yang tersusun dari asam kuat dan basa lemah, maka sebagian siswa sudah dapat dikatakan memperoleh konsep reaksi hidrolisis garam yang tersusun dari asam kuat dan basa lemah. Siswa lainnya sebanyak 13 (36,11\%) tidak mampu memperoleh konsep reaksi hidrolisis garam dari asam kuat dan basa lemah dengan baik.

Pemahaman siswa tentang konsep reaksi hidrolisis garam yang tersusun dari asam kuat dan basa lemah ditelusuri menggunakan butir soal 2a. Skor yang diberikan pada butir soal 2a berada pada rentang 0-3 untuk larutan garam yang logamnya berbilangan oksidasi I maupun larutan garam yang logamnya berbilangan oksidasi II. Skor maksimum yang dapat diperoleh pada butir soal 2a adalah 6. Deskripsi pemahaman siswa dan skor disajikan pada Tabel 12.

Tabel 12. Deskripsi Pemahaman dan Skor pada Butir Soal 2a

\begin{tabular}{|c|c|}
\hline $\begin{array}{c}\text { Deskripsi Pemahaman } \\
\end{array}$ & Skor \\
\hline \multicolumn{2}{|l|}{ Reaksi hidrolisis garam dari larutan garam yang logamnya berbilangan oksidasi I } \\
\hline Siswa tidak memahami (jawaban siswa tidak relevan/salah). & 0 \\
\hline $\begin{array}{l}\text { Siswa dapat menuliskan reaksi ionisasi dari lantan garam yang logamnya } \\
\text { berbilangan oksidasi I. }\end{array}$ & 1 \\
\hline $\begin{array}{l}\text { Siswa dapat menuliskan reaksi asam konjugasi kuat dengan air dari lantan garam } \\
\text { yang logamnya berbilangan oksidasi I. }\end{array}$ & 2 \\
\hline $\begin{array}{l}\text { Siswa dapat menuliskan reaksi hidrolisis garam dari lanutan garam yang logamnya } \\
\text { berbilangan oksidasi I. }\end{array}$ & 3 \\
\hline $\begin{array}{c}\text { Deskripsi Pemahaman } \\
\end{array}$ & Skor \\
\hline \multicolumn{2}{|l|}{ Reaksi hidrolisis garam dari larutan garam yang logamnya berbilangan oksidasi II } \\
\hline Siswa tidak memahami (jawaban siswa tidak relevan/salah). & 0 \\
\hline $\begin{array}{l}\text { Siswa dapat menuliskan reaksi ionisasi dari lantan garam yang logamnya } \\
\text { berbilangan oksidasi } I \text {. }\end{array}$ & 1 \\
\hline $\begin{array}{l}\text { Siswa dapat menuliskan reaksi asam konjugasi kuat dengan air dari lantan garam } \\
\text { yang logamnya berbilangan oksidasi II. }\end{array}$ & 2 \\
\hline $\begin{array}{l}\text { Siswa dapat menuliskan reaksi hidrolisis garam dari lantan garam yang logannya } \\
\text { berbilangan oksidasi II. }\end{array}$ & 3 \\
\hline
\end{tabular}

Data jumlah siswa pada tiap skor yang diperoleh saat pretes dan postes disajikan pada Tabel 13 untuk larutan garam yang logamnya berbiloks I dan Tabel 14 untuk larutan garam yang logamnya berbiloks II.

Tabel 13. Jumlah Siswa pada Tiap Skor saat Pretes dan Postes pada Butir Soal 2a Biloks I

\begin{tabular}{ccccc}
\hline \multirow{2}{*}{ Skor } & \multicolumn{5}{c}{ Jumlah Sisma } \\
\cline { 2 - 5 } & \multicolumn{2}{c}{ Pretes } & \multicolumn{3}{c}{ Postes } \\
\cline { 2 - 5 } & Sisma & $\%$ & Sisma & $\%$ \\
\hline 0 & 28 & 77,78 & 6 & 16,67 \\
\hline 1 & 3 & 8,33 & 2 & 5,56 \\
\hline 2 & 5 & 13,89 & 5 & 13,99 \\
\hline 3 & - & - & 23 & 63,99 \\
\hline
\end{tabular}

Tabel 13 menunjukkan bahwa pada awal pembelajaran (pretes) ada $28(77,78 \%)$ siswa yang tidak mampu menuliskan reaksi hidrolisis garam yang tersusun dari asam kuat dan basa lemah pada garam yang logamnya berbiloks I. Hal ini dikarenakan siswa pada saat pretes belum memahami reaksi hidrolisis garam yang tersusun dari asam kuat dan basa lemah. Siswa pada akhir pembelajaran (postes) sebagian besar sudah mampu menuliskan reaksi hidrolisis garam yang logamnya berbiloks I dengan baik, yakni sebanyak $23(63,89 \%)$ siswa. Hal ini menandakan sebagian 
besar siswa sudah memahami konsep reaksi hidrolisis garam dari asam kuat dan basa lemah.

Tabel 14. Jumlah Siswa pada Tiap Skor saat Pretes dan Postes pada Butir Soal 2a Biloks II

\begin{tabular}{ccccc}
\hline \multirow{2}{*}{ Skor } & \multicolumn{4}{c}{ Jumlah Sisma } \\
\cline { 2 - 5 } & \multicolumn{2}{c}{ Pretes } & \multicolumn{2}{c}{ Postes } \\
\cline { 2 - 5 } & Sisma & $\%$ & Sisma & $\%$ \\
\hline 0 & 34 & 94,44 & 7 & 19,44 \\
\hline 1 & 2 & 5,56 & 8 & 22,22 \\
\hline 2 & - & - & 6 & 16,67 \\
\hline 3 & - & - & 15 & 41,67 \\
\hline
\end{tabular}

Tabel 14 menunjukkan hampir seluruh siswa tidak mampu menuliskan reaksi hidrolisis garam dari asam kuat dan basa lemah dengan logam berbiloks II, yakni sebanyak 34 (94,44\%) siswa. Siswa kemungkinan besar pada saat pretes belum memahami konsep dan konsep dasar siswa tentang penyetaraan reaksi masih lemah, sehingga siswa siswa tidak dapat menjawab pretes dengan baik. Siswa pada saat postes hanya 15 $(41,67 \%)$ orang yang memahami konsep ini dengan baik. Hal ini dikarenakan sebagian besar siswa mampu memperoleh konsep tetapi tidak mampu menerapkan konsep, sehingga dapat dikatakan bahwa sebagian besar siswa belum memahami konsep ini dengan baik.

\section{Konsep Sifat Larutan Garam yang Terbentuk dari Asam Kuat dan Basa Lemah Berdasarkan Reaksi Hidrolisis (Konsep Teoritis)}

Ada $34(94,44 \%)$ siswa sebagaimana ditunjukkan pada Tabel 5 yang dapat memperoleh konsep teoritis tentang sifat larutan garam yang tersusun dari asam kuat dan basa lemah berdasarkan reaksi hidrolisis garamnya. Jumlah siswa tersebut menunjukkan hampir seluruh siswa sudah mampu menemukan konsep bahwa larutan garam yang berasal dari asam kuat dan basa lemah bersifat asam karena menghasilkan $\mathrm{H}^{+}$pada akhir reaksi. Tabel 5 menunjukkan hanya ada $2(5,56 \%)$ siswa yang masih belum mampu memperoleh konsep bahwa larutan garam yang tersusun dari asam kuat dan basa lemah adalah bersifat asam.

Pemahaman siswa tentang konsep sifat (asam/basa) larutan garam yang tersusun dari asam kuat dan basa lemah berdasarkan reaksi hidrolisis garam secara teoritis ditelusuri menggunakan butir soal 2 b. Skor yang diberikan pada butir soal $2 \mathrm{~b}$ berada pada rentang 0-2. Deskripsi pemahaman siswa dan skor disajikan pada Tabel 15.

Tabel 15. Deskripsi Pemahaman dan Skor pada Butir Soal 2b

\begin{tabular}{|c|c|}
\hline Deskripsi Pemahaman & Skor \\
\hline Siswa tidak memahami (jawaban siswra tidalk relevan/salah). & 0 \\
\hline $\begin{array}{l}\text { Siswa dapat menentukan sifat lanutan garam dari asam kuat dan basa lemah yang } \\
\text { logannya berbilangan oksidasi I berdazatkan reaksi hidrolisisnya. }\end{array}$ & 1 \\
\hline $\begin{array}{l}\text { Siswa dapat menentukan sifat lanutan gatam dari asam kuat dan basa lemah yang } \\
\text { logamnya berbilangan oksidasi I I berdazadkan reaksi hidrolisisnya. }\end{array}$ & 2 \\
\hline
\end{tabular}

Data jumlah siswa pada tiap skor yang diperoleh saat pretes dan postes disajikan pada Tabel 16.

Tabel 16. Jumlah Siswa pada Tiap Skor saat Pretes dan Postes pada Butir Soal 2b

\begin{tabular}{ccccc}
\hline \multirow{2}{*}{ Skor } & \multicolumn{5}{c}{ Jumlah Sisma } \\
\cline { 2 - 5 } & \multicolumn{3}{c}{ Pretes } & \multicolumn{3}{c}{ Postes } \\
\cline { 2 - 5 } & Sisma & $\%$ & Sisma & $\%$ \\
\hline 0 & 31 & 86,11 & - & - \\
\hline 1 & 5 & 13,89 & 4 & 11,11 \\
\hline 2 & - & - & 32 & 88,89 \\
\hline
\end{tabular}


Tabel 16 menunjukkan bahwa pada awal pembelajaran (pretes) ada $31(86,11 \%)$ siswa yang tidak mampu menentukan sifat asam/basa larutan garam yang tersusun dari asam kuat dan basa lemah berdasarkan reaksi hidrolisis. Hal ini dikarenakan pada saat pretes siswa belum menerima pembelajaran tentang hidrolisis garam yang tersusun dari asam kuat dan basa lemah. Siswa pada akhir pembelajaran (postes) sebagian kecil hanya mampu menentukan sifat asam/basa larutan garam berdasarkan reaksi hidrolisis garam yang logamnya berbiloks I, yakni sejumlah $4(11,11 \%)$ siswa. Siswa tersebut diduga belum mampu menerapkan dengan baik konsep yang diperoleh, sehingga tidak mampu mendapatkan hasil yang maksimal pada saat mengerjakan postes.

\section{Korelasi Antara Kemampuan Siswa Menyelesaikan Tahapan Belajar Penemuan dengan Kemampuan Siswa Memperoleh Konsep dan Kemampuan Siswa Memahami Konsep}

Korelasi antara kemampuan siswa menyelesaikan tahapan belajar penemuan dengan kemampuan siswa memperoleh konsep dan kemampuan siswa memahami konsep disajikan pada Tabel 17. Korelasi antara kemampuan siswa menyelesaikan tahapan belajar penemuan dengan kemampuan siswa memperoleh konsep dan kemampuan siswa memahami konsep disajikan juga dalam bentuk grafik yang ditunjukkan pada Gambar 1.

Tabel 17. Korelasi Antara Kemampuan Siswa Menyelesaikan Tahapan Belajar Penemuan dengan Kemampuan Siswa Memperoleh Konsep danKemampuan Siswa Memahami Konsep

\begin{tabular}{|c|c|c|c|}
\hline Kode Sisun & $\begin{array}{c}\text { Kemampan Sirra } \\
\text { Meryelesailien Tahapan } \\
\text { Belajer (\$i) }\end{array}$ & $\begin{array}{c}\text { Kemampan Siruz } \\
\text { Semperoleh Komep (5i) }\end{array}$ & 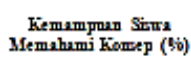 \\
\hline I-1 & 83,48 & 80,52 & 83,33 \\
\hline $\mathrm{I}-2$ & 83,48 & 80,68 & 83,33 \\
\hline $\mathrm{I}-3$ & 82,61 & 85,80 & 100,00 \\
\hline $\mathrm{I}-4$ & 80,00 & 84,50 & 100,00 \\
\hline I-5 & 81,74 & 82,09 & 91,67 \\
\hline II-1 & 80,87 & 84,77 & 100,00 \\
\hline II-2 & 83,48 & 69,57 & 50,00 \\
\hline II-3 & 81,74 & 85,04 & 100,00 \\
\hline II-4 & 81,74 & 85,04 & 100,00 \\
\hline II-5 & 85,22 & 81,55 & 83,33 \\
\hline III-1 & 91,30 & 90,15 & 100,00 \\
\hline III-2 & 81,74 & 85,20 & 100,00 \\
\hline III-3 & 86,96 & 76,87 & 66,67 \\
\hline III-4 & 80,00 & 70,28 & 58,33 \\
\hline IV-1 & 85,22 & 84,16 & 91,67 \\
\hline IV-2 & 81,74 & 85,20 & 100,00 \\
\hline IV-3 & 91,30 & 90,15 & 100,00 \\
\hline IV-4 & 90,43 & 73,05 & 50,00 \\
\hline IV-5 & 92,17 & 87,81 & 91,67 \\
\hline V-1 & 87,83 & 77,30 & 66,67 \\
\hline V-2 & 85,22 & 81,39 & 83,33 \\
\hline $\mathrm{V}-3$ & 86,96 & 79,48 & 75,00 \\
\hline $\mathrm{V}-4$ & 88,70 & 88,85 & 100,00 \\
\hline VI-1 & 83,48 & 72,35 & 58,33 \\
\hline VI-2 & 85,22 & 78,28 & 75,00 \\
\hline VI-3 & 84,35 & 69,67 & 50,00 \\
\hline VI-4 & 80,87 & 73,16 & 66,67 \\
\hline VII-1 & 92,17 & 90,59 & 100,00 \\
\hline VII-2 & 84,35 & 74,73 & 66,67 \\
\hline VII-3 & 92,17 & 73992 & 50,00 \\
\hline VII-4 & 92,17 & 90,59 & 100,00 \\
\hline VIII-1 & 84,35 & 85,67 & 100,00 \\
\hline VIII-2 & 82,61 & 71,75 & 58,33 \\
\hline VIII-3 & 91,30 & 87,21 & 91,67 \\
\hline VIII-4 & 85,22 & 86,44 & 100,00 \\
\hline VIII-5 & 87,83 & 80,08 & 75,00 \\
\hline
\end{tabular}

Tabel 17 menunjukkan bahwa sebanyak 11 (30,56\%) siswa memiliki data yang tidak sinkron antara kemampuan menyelesaikan tahapan belajar penemuan dengan kemampuan memperoleh konsep dan kemampuan memahami konsep. Data pemahaman konsep siswa tersebut 
jauh lebih rendah dibandingkan data kemampuan siswa menyelesaikan tahapan belajar penemuan dan data memperoleh konsep.

Gambar 1. Korelasi Antara Kemampuan Siswa Menyelesaikan

Tahapan Belajar Penemuan dengan Kemampuan Siswa Memperoleh Konsep dan Kemampuan Siswa Memahami Konsep

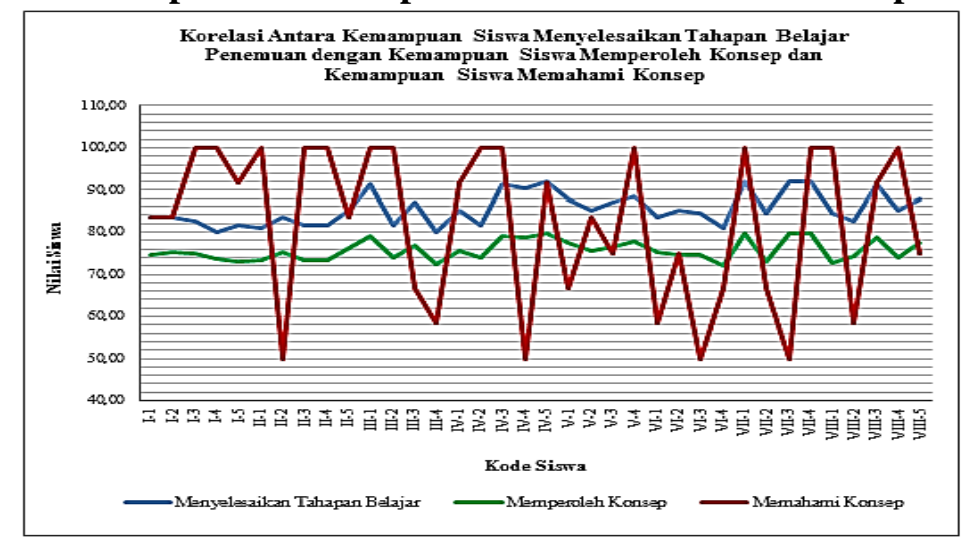

Gambar 1 menunjukkan bahwa kurva kemampuan siswa menyelesaikan tahapan belajar penemuan dengan kurva kemampuan siswa memperoleh konsep dan kurva kemampuan siswa memahami konsep ini tidak sejajar (tidak sinkron). Data yang tidak sinkron ini disebabkan oleh ketidakmampuan siswa menerapkan konsep yang telah ditemukan pada saat proses pembelajaran. Siswa yang tidak mampu memahami konsep kemungkinan besar dikarenakan siswa tersebut pada saat mengerjakan LKS hanya menyalin jawaban teman satu kelompoknya saja sehingga siswa tidak memperoleh konsep dengan optimal yang mengakibatkan pemahaman konsep siswa tersebut juga tidak optimal.

\section{SIMPULAN}

Kesimpulan dari hasil penelitian yang telah dilakukan, yaitu:

1. Kemampuan siswa memperoleh konsep hidrolisis garam dari asam kuat dan basa lemah dalam pembelajaran menggunakan LKS berbasis belajar penemuan tercermin dari jumlah siswa yang memperoleh konsep, yaitu rata-rata sebesar $82,64 \%$.

2. Kemampuan siswa memahami konsep hidrolisis garam dari asam kuat dan basa lemah dalam pembelajaran menggunakan LKS berbasis belajar penemuan rata-rata sebesar $89,81 \%$.

\section{REFERENSI}

Arikunto, S., 2013, Dasar-dasar Evaluasi Pendidikan (Edisi Kedua), PT. Bumi Aksara, Jakarta.

Dahar, R.W., 2011. Teori-teori Belajar dan Pembelajaran, PT. Gelora Aksara Pratama, Jakarta

Latifah, S., Sugiharto, dan Nugroho, A., 2014, Studi Komparasi Penggunaan Praktikum dan Demonstrasi pada Metode Problem Solving terhadap Prestasi Belajar Siswa Materi Hidrolisis Garam Kelas XI Ilmu Alam SMA Al Islam 1 Surakarta Tahun Pelajaran 2010/2011, Jurnal Pendidikan Kimia, 3(3): 2337-9995

Moeljadi, D., dkk, 2016, Kamus Besar Bahasa Indonesia (Edisi Kelima), Badan Pengembangan dan Pembinaan Bahasa, Kementrian Pendidikan dan Kebudayaan Republik Indonesia, Jakarta. 
Nurisalfah, R., 2015, Pengembangan LKS Menggunakan Model Discovery Learning pada Materi Teori Atom Mekanika Kuantum. Jurnal Pendidikan dan Pembelajaran Kimia, 4(1): 197-208

S., Masrura Linda., 2017, Penggunaan LKS Berbasis Discovery Learning pada Materi Asam Basa terhadap Hasil Belajar Siswa di MAS Oemar Diyan Aceh Besar, Skripsi, Program Studi Pendidikan Kimia, Fakultas Tarbiyah dan Keguruan, Universitas Islam Negeri ArRaniry Darussalam Banda Aceh, Aceh. Tidak Dipublikasikan.

Seçken, N., \& Evrim U.A., 2011, The Effect of Constructivist Approach on Students' Understanding of The Concepts Related to Hydrolysis, Procedia Social and Behavioral, 15: 235-240

Setianto, R. Muharini, \& R.R., 2017, Pengaruh Model Guided Discovery Learning terhadap Pemahaman Konsep Siswa pada Materi Hidrolisis Garam, Skripsi, Program Studi Pendidikan Kimia, Fakultas Keguruan dan Ilmu Pendidikan, Untan Pontianak. Tidak Dipublikasikan.

Suyanti, R.D., 2010, Strategi Pembelajaran Kimia, Graha Ilmu. Yogyakarta.

Suyono dan Hariyanto, 2012, Belajar dan Pembelajaran, PT. Remaja Rosdakarya, Bandung.

Ulaş, A.H, Oğuzhan Sevim., \& Esengül Tan., 2012, The Effect of Worksheets Based Upon 5e Learning Cycle Model on Student Success in Teaching of Adjectives as Grammatical Components. Procedia Social and Behavioral Sciences, 31: 391-398

Utami, D.D, Budi Hastuti., \& Tri Redjeki., 2015, Upaya Peningkatan Aktivitas dan Prestasi Belajar Siswa Kelas XI IPA 2 dengan Menggunakan Model Pembelajaran Kooperatif Tipe Team Assisted Individualization (TAI) Berbantuan Demonstrasi pada Materi Hidrolisis Garam di SMA Negeri 1 Banyudono Boyolali Tahun Pelajaran 2013/2014. Jurnal Pendidikan Kimia, 4(1): 2337-9995.

\section{UCAPAN TERIMA KASIH}

Saya mengucapkan terima kasih kepada Tuhan YME karena atas berkat dan kasih-Nya saya dapat menyelesaikan jurnal yang berjudul "kemampuan siswa memperoleh dan memahami konsep hidrolisis garam dalam pembelajaran menggunakan LKS berbasis belajar penemuan pada siswa kelas XI SMAN 2 Palangka Raya tahun ajaran 2018/2019”. Tak lupa juga, saya mengucapkan terima kasih kepada kedua orangtua saya serta sanak kerabat, sahabat, dan teman-teman saya yang telah memberikan dukungan moral maupun materiil terhadap penyelesaian jurnal ini. 